\title{
Maternal Knowledge, Husband's Support, Cultural Support and Role of Health Workersin the Exclusive Breastfeeding Program at Mojosari Health Center
}

\author{
Dyah Siwi Hety ${ }^{1}$, Ika Yuni Susanti ${ }^{2}$, Ferilia Adiesti ${ }^{3}$, Abdul Muhith ${ }^{4}$ \\ \{abdulmuhith@unusa.ac.id, dyahsiwi11@gmail.com, \} \\ 1,2,3,STIKes Majapahit Mojokerto, \\ ${ }^{4}$ Nursing science Department - University of Nahdlatul Ulama Surabaya (UNUSA)
}

\begin{abstract}
Exclusive breastfeeding is very necessary until the baby is 6 months old. But until now only about $13 \%$ of mothers who give exclusive breastfeeding to their babies. The purpose of this study was to determine the factors that influence exclusive breastfeeding for breastfeeding mothers in the working area of the Mojosari Health Center. This research is quantitative analytic research with the cross-sectional approach. Factors identified include the mother's knowledge, husband's support, health worker support, and social culture. Data collection is done by questionnaire. The number of respondents was 37 mothers who had babies less than 6 months old with a simple random sampling technique. The data obtained were processed statistically using logistic regression tests to determine the factors that influence exclusive breastfeeding. Statistical test results show that variables that significantly influence exclusive breastfeeding are maternal knowledge ( $\mathrm{p}$-value $=0.01$; OR $15.332(95 \% \mathrm{CI}$ $(5,242-33,334))$, husband's support (p-value $=0.03$; OR $9,838(95 \%$ CI $(95 \%$ CI) $4,452-19,433)$ ), cultural support ( $p$ value $=0.002$; OR of $21,442(95 \% \mathrm{CI}$ $(7,739-42,347))$ and support of health workers ( $\mathrm{p}$ value $=0.01 ; 11,453(95 \% \mathrm{CI}$ $(3,533-29,452))$. The success factor of exclusive breastfeeding in addition to knowledge is certainly accompanied by the mother's own will. The role of health workers is the biggest influence on mothers in the exclusive breastfeeding process. The success of exclusive breastfeeding also does not escape from family support because the family is the closest person who can encourage mothers to continue to give exclusive breastfeeding and also the culture around that encourages exclusive breastfeeding.
\end{abstract}

Keywords: exclusive breastfeeding, knowledge, husband support, culture,

\section{Intrduction}

The ability of qualified Human Resources (HR) is by the needs of the body. The progress of the Indonesian people in the future is determined by intelligent generations, therefore improving nutrition must start early. The provision of proper nutrition for children from birth will greatly affect the quality of human resources in the future, more attention from parents and health services must be able to pay attention to proper nutrition for children from birth 
(Maramis, et al, 2019). In supporting health and also child mortality, the United Nations Fund (UNICEF) and the World Health Organization (WHO), children who receive breastfeeding are only breastfed for at least six months. Solid food is given after the baby is six months old and gives breastmilk which is received by children for two years (Indonesian Ministry of Health, 2015). WHO data shows exclusive breastfeeding in infants aged 0-6 months worldwide by $39 \%$ (WHO, 2016). According to the UNICEF (United Nations International Children's Emergency Fund) report in 2011 at the World Breastfeeding Week (2018), as many as $136,700,000$ babies were received worldwide and only $32.6 \%$ of those who were exclusively breastfed during 0 to First 6 months. Exclusive breastfeeding is below $80 \%$ and there are still mothers who give exclusive breastfeeding to babies.

Based on Indonesian health profile data it is obtained that the coverage of exclusive breastfeeding for 0-6 months at the level of East Java province from 2013 the percentage was $47.88 \%$ to $74 \%$ in 2014 , in this case, there was a significant increase but the percentage of exclusive breastfeeding in East Java have not reached the National target of $80 \%$. (Indonesian Ministry of Health, 2015). Data from the Mojokerto District Health Office, obtained coverage of exclusive breastfeeding in Mojokerto in 2017, from the number of babies 6-6 months in 2017 as many as 13,977 infants, the coverage of exclusive breastfeeding was $10.312(73.8 \%)$, which decreased when compared to 2016. (Mojokerto Health Office, 2017). To support the success in breastfeeding, the rules and laws governing exclusive breastfeeding, namely Law Number 36 of 2009 concerning health, article 128, paragraph 1, states that every baby has the right to receive exclusive breast milk from birth for 6 (six) months, except for medical indications. ; and paragraph 2 During breastfeeding, the family, local government and community must support the mother in full by providing special time and facilities (Indonesian Ministry of Health, 2015)

Government Regulation No. 33 of 2012 concerning the Provision of Exclusive Breastfeeding regulates the role of government in increasing exclusive breastfeeding, which includes the role of health workers and health services. In PP No. 33 of 2012 also explained the provision of information or health promotion to the community (Ministry of Health, 2012). Community Health Centers or Puskesmas are primary health care services that have an important role in preventive and promotive activities besides curative and rehabilitative activities. Puskesmas which include health promotion which of course are run by officers should be more able to maximize roles and responsibilities based on regulations and regulations that apply to achieve success in exclusive breastfeeding. Health promotion is the spearhead of the puskesmas in delivering health messages to the community to improve the degree of public health.

\section{Method}

The research used is Cross-Sectional design. The population in this study were all mothers who had babies less than six months old in the Mojosari sub-district in the working area of the Mojsari Community Health Center in May 2019. The sample was 37 people and was taken using a simple random sampling technique. The independent variable is knowledge, husband's support, social culture, and the role of health workers. dependent variable exclusive breastfeeding. Data was collected using a questionnaire. Data analyzed with Logistic Regression. 


\section{Result And Discussion}

Table 1. Maternal Knowledge, Husband's Support, Cultural Support and Role of Health Workers in the Exclusive Breastfeeding Program at Mojosari Health Center

\begin{tabular}{lllll}
\hline \multirow{2}{*}{ variable } & P Value & \multirow{2}{*}{ OR } & \multicolumn{2}{c}{ CI 95\% } \\
\cline { 3 - 5 } & & & Lower & Upper \\
\hline Knowledge & 0.01 & 15.323 & 5.242 & 33.342 \\
\hline Husband's Support & 0.03 & 9.838 & 4.452 & 19.433 \\
\hline Culture's Support & 0.002 & 21.423 & 7.739 & 42.347 \\
\hline Role of Health Officers & 0.01 & 11.453 & 3.533 & 29.452 \\
\hline
\end{tabular}

Based on the results of the study showed that of several factors that showed, the knowledge factor showed p-value $=0.01$ with OR 15.332 (95\% CI $(5.242$ - 33.334)), which means there is a relationship between maternal knowledge and the help of exclusive breastfeeding. The next factor was husband's support, the results showed the value of $\mathrm{p}=0.03$ with OR 9.838 (95\% CI (4.452 - 19.433)), which meant there was a relationship between husband's support and exclusive breastfeeding. The third factor is Cultural Support, the research results show the value of $p=0.002$ with an OR of $21.442(95 \%$ CI $(7,739-42,347))$, which means there is a relationship between cultural support and exclusive breastfeeding. The last factor is the role of health workers, the results of the study showed a p-value $=0.01$ with OR 11.453 (95\% CI (3.533 - 29.452)), which means there is a relationship between the role of health workers with the help of exclusive breastfeeding.

\subsection{Relationship between Maternal Knowledge and Exclusive Breastfeeding}

Based on the results of the study showed that of several factors that showed, the knowledge factor showed $\mathrm{p}$-value $=0.01$ with OR 15.332 (95\% CI $(5.242-33.334))$, which means there is a relationship between maternal knowledge and the help of exclusive breastfeeding. The frequency distribution of respondents shows that the majority of respondents have a good level of knowledge about exclusive breastfeeding (74\%).

Knowledge is one of the predisposing factors that determine a person's health behavior. Such knowledge can be obtained through formal education, counseling, and information from the mass media. Mother's knowledge is everything that is known by the mother related to exclusive breastfeeding, which includes: understanding exclusive breastfeeding, the benefits of exclusive breastfeeding, colostrum and lactation management that supports the success of exclusive breastfeeding for infants up to 6 months of age as stipulated by the government. (Cascone et al, 2019) Good knowledge is obtained from a good learning process. Thus the cause of the high number of respondents who have good knowledge, one of which is the information received by respondents when getting an education, because most of the respondents had a high school education (Astuti \&Adimayanti, 2016). The level of education has an important role in determining the quality of human beings with education, humans are considered to gain knowledge. The higher the education, the better the quality of human life. Likewise, with exclusive breastfeeding, mothers with better levels of education will increasingly understand the positive impact of exclusive breastfeeding for their babies. In other words, it can be said that the higher education of mothers will make understanding the importance and benefits of exclusive breastfeeding better. Mothers with higher education will understand how and the impact that will be obtained by understanding how to care for and maintain the health of babies (Hall et al., 2018) 


\subsection{Relationship between Husband's Support and Exclusive Breastfeeding}

Based on the results of the study showed that husband's support has p-value $=0.03$ with OR 9.838 (95\% CI (4.452 - 19.433)), which meant there was a relationship between husband's support and exclusive breastfeeding.

The distribution of respondents shows that the majority of respondents has support from her husband to provide exclusive breastfeeding (84\%).

Family support is a supporting factor in the success of exclusive breastfeeding. This family support is an emotional and psychological activity given to breastfeeding mothers in breastfeeding. This is related to thoughts, feelings, and sensations that can facilitate the production of breast milk (Maramis et al, 2019)

Support is a positive pattern of interaction or helping behavior given to individuals in the face of an event or a pressing event. The support felt by the individual in his life makes her feel to be loved, valued, and recognized and makes himself more meaningful and can optimize the potential that exists in him. People who get support will feel part of the support provider the success of the process of breastfeeding is inseparable from a husband who supports his wife. The husband is the closest person to be expected to be there and always ready to provide help and support. A husband must be able to explain to his wife that a mother who takes longer to breastfeed her child has a good emotional relationship with her child, and is more confident than those who are fast weaning (Muhith et al., 2018)

Husbands who support exclusive breastfeeding programs can affect the mental health of the mother to be healthy. This is because of the creation of a comfortable atmosphere. Husband's attention is needed by the wife in the process of producing milk, namely reflex oxytocin, where a positive-thinking mother can stimulate the muscles around the mammary glands to contract, then breast milk will flow into the lactiferous sinus and then the baby can drink it. Family presence is very important to encourage mothers to increase self-confidence and stabilize their emotions, as well as providing great motivation for breastfeeding mothers (Ratnasari et al., 2017)

The influence of increasingly modern lifestyles and the husband's busyness to look for material, so that makes the husband less concerned and less supportive towards exclusive breastfeeding, so many breastfeeding mothers who give supplementary milk earlier. The husband's lack of knowledge about the benefits of breast milk, as well as the advertisement/promotion of formula milk, makes the husband support to provide additional food or formula milk. The role of the family in supporting nursing mothers influences the success of exclusive breastfeeding. Support coming from families, whether husband, mother, in-laws and other family members who already have breastfeeding experience, usually becomes dominant towards mothers (Fitri et al., 2017)

\section{3 Relationship between Cultural Support and Exclusive Breastfeeding}

Based on the results of the study showed that cultural support, the research results show the value of $p=0.002$ with an OR of $21.442(95 \%$ CI $(7,739-42,347))$, which means there is a relationship between cultural support and exclusive breastfeeding. The distribution of respondents shows that the majority of respondents has a positive support from her culture to provide exclusive breastfeeding $(63 \%)$. Social culture is everything created by humans with their thoughts and conscience for and or in social life. Or in short, humans make things based on their minds and minds which are destined for social life. Strong mother's confidence or trust is an important determinant factor in the success of exclusive breastfeeding. Trust or belief influences attitudes toward certain behaviors, subjective norms, and control of behavior. 
Various socio-cultural factors underlying the behavior of exclusive breastfeeding are related to people's habits in providing food to newborn babies. (Basrowi et al., 2015)

Socio-culture greatly influences the behavior of mothers if socio-culture supports exclusive breastfeeding, it is expected that mothers will also succeed in providing exclusive breastfeeding, diverse socio-cultural diversity in society should be filtered by which health workers are good according to health and which are not good. local is usually very influential on the formation of one's behavior. For traditional communities breastfeeding is not a big problem because in general mothers give their babies breast milk, but what happens is the pattern of breastfeeding that is not following medical concepts so that it harms the health and growth of infants (Spagnoletti et al.,2017).

\section{4. Relationship between Role of Health Officer and Exclusive Breastfeeding}

Based on the results of the study showed that role of the health officer, the research results show the value of $p=0.01$ with OR 11.453 (95\% CI (3.533 - 29.452)), which means there is a relationship between the role of health workers with the help of exclusive breastfeeding.

The distribution of respondents shows that the majority of respondents has positive support from health officer to provide exclusive breastfeeding $(83 \%)$.

Health workers are the main component involved

play a role and will make a very important contribution to the success of efforts to promote and encourage breastfeeding, these health workers have a big part in efforts to increase the use of breast milk in addition to the factors that exist in the community itself. A strong commitment from health workers or health providers (doctors, midwives, nurses, hospital management and others) in the promotion of breastfeeding is needed because they are always in direct contact with the community and have many opportunities and can provide explanations and counseling about breast milk. The role of health workers in exclusive breastfeeding is very important. The average female in Indonesia gives birth in a hospital or midwife. The trusted advice for children's health is health workers. So, health workers play a key role in this regard, specifically to get exclusive breastfeeding at a hospital or maternity hospital (Ratnasari et al., 2017)

A healthcare worker is someone who is respected, respected in the eyes of clients because they are of high status according to their education. Its role in health is very much needed, for that health workers must be able to provide conditions that can affect positive behavior towards health. Health workers will try to improve the health of clients by influencing their behavior. The influence depends on persuasive communication aimed at the client including attention, understanding, recipient's memory, and behavior change. With this communication will be created and maintained a relationship that will help positive things to encourage clients to take action that is beneficial to the health of themselves and their families. (Basrowi et al., 2015) Social support from health workers can be seen when staff carries out health services, namely by explaining, inviting, giving sympathy and giving examples for healthy behavior. Encouragement of health workers in exclusive breastfeeding is to protect and enhance the behavior of breastfeeding mothers both exclusively and to breastfeed babies for up to 2 years and help mothers solve barriers and problems related to breastfeeding, as well as provide information to mothers about lactation management and encourage breastfeeding with foster mother's trust (Permatasari et al., 2018) 


\section{Conclusions}

Based on the results of research and discussion of factors that influence exclusive breastfeeding at the Mojosari Community Health Center. Some conclusions are that there is a relationship between the mother's knowledge, husband's support, cultural support, and the role of health workers in the exclusive breastfeeding program. The government can make written policies about exclusive breastfeeding and supervise and evaluate the extension program. health workers carry out extension activities on exclusive breastfeeding regularly and evenly every month.

\section{Refrence}

[1] Astuti, A. P., \& Adimayanti, E. (2016). Gambaran Pengetahuan Ibu Tentang Cara Pemberian Asi Eksklusif yang Baik pada Bayi Usia 0-6 Bulan di Desa Gogodalem Barat Kecamatan Bringin Kabupaten Semarang. Jurnal Keperawatan Anak, 3(1), 1-4.

[2] Basrowi, R. W., Sulistomo, A. B., Adi, N. P., \& Vandenplas, Y. (2015). Benefits of a dedicated breastfeeding facility and support program for exclusive breastfeeding among workers in Indonesia. Pediatric gastroenterology, hepatology \& nutrition, 18(2), 94-99.

[3] Cascone, D., Tomassoni, D., Napolitano, F., \& Di Giuseppe, G. (2019). Evaluation of Knowledge, Attitudes, and Practices about Exclusive Breastfeeding among Women in Italy. International journal of environmental research and public health, 16(12), 2118.

[4] Fitri, N., Lestari, Y., \& Evareny, L. (2017). The Relation Between Husband Support with Exclusive Breastfeeding in Baby Age 6-12 Months in Air Dingin Health Center. Journal of Midwifery, 2(2), 74-81.

[5] Hall, C., Bennett, C., Crookston, B., Dearden, K., Hasan, M., Linehan, M., ... \& West, J. (2018). Maternal Knowledge of Stunting in Rural Indonesia. International Journal of Child Health and Nutrition, 7(4), 139-145

[6] Maramis, F. I., Tumurang, M., \& Kalesaran, A. F. (2019). Peran Petugas Promosi Kesehatan, Pengetahuan Ibu Dan Dukungan Keluarga Dalam Meningkatkan Pemberian Asi Eksklusif Di Wilayah Kerja Puskesmas Airmadidi Kabupaten Minahasa Utara. KESMAS, 6(4).

[7] Ministry of Health of Republic Indonesia. (2015). Profil Kesehatan Indonesia 2015. Jakarta: Kementerian Kesehatan Republik Indonesia.

[8] Mojokerto Health Office. (2017). Profil Kesehatan Kabupate Mojokerto Tahun 2016. Mojokerto.

[9] Muhith, A., Fardiansyah, A., \& Saputra, M. H. (2018). Analysis of Causes and Impacts of Early Marriage on Madurese Sumenep East Java Indonesia. Indian Journal of Public Health Research \& Development, $9(8)$.

[10] Permatasari, T. A. E., Sartika, R. A. D., Achadi, E. L., Purwono, U., Irawati, A., Ocviyanti, D., \& Martha, E. (2018). Exclusive Breastfeeding Intention among Pregnant Women. Kesmas: National Public Health Journal, 12(3), 134-141.

[11] Ratnasari, D., Paramashanti, B. A., Hadi, H., Yugistyowati, A., Astiti, D., \& Nurhayati, E. (2017). Family support and exclusive breastfeeding among Yogyakarta mothers in employment. Asia Pacific journal of clinical nutrition, 26(Supplement), S31.

[12] Spagnoletti, B. R., Bennett, L. R., Kermode, M., \& Wilopo, S. A. (2017). Multitasking breastfeeding mamas: middle class women balancing their reproductive and productive lives in Yogyakarta, Indonesia. Breastfeeding Review, 25(3), 13.

[13] Muhith A., and Herlambang, T. 2019. "Estimation of Availability of Whole Blood (WB) at PMI Surabaya City Using Kalman Filter as Management of Blood Bank", The 1ST International Conference On Bussines, Law, And Pedagogy, 13-14 February 2019

[14] Muhith A., and Herlambang, T. 2019. "Estimation of Packed Red Cells (PRC) Blood Stock Using Extended Kalman Filter as Management of Blood Transfusion at Blood Bank of PMI 
Surabaya", The 1ST International Conference On Bussines, Law, And Pedagogy, 13-14 February 2019

[15] Muhith A., Herlambang, T., Zuhdi, U., and Rahmalia, D. 2019. "Estimation of Availability of Whole Blood (WB) and Washed Erythrocyte (WE) Using Ensemble Kalman Filter as Blood Transfusion Management in PMI Surabaya", Seminar International Health Conference, 13-14 July 2019

[16] Muhith A., Herlambang, T., Haris, A., and Rizqina, R. 2019. "Estimation of Whole Blood (WB) using Unscented Kalman Filter for Blood Bank Management", The International Conference On Bussines and Management of Technology, 3 August 2019.

[17] Muhith, A dkk (2019). Evaluating Anxiety, Self-Efficacy and Positive Attitude Correlation Towards Mathematics Through Fuzzy Correlation Utilization. Journal of Engineering and Applied Sciences Volume: 14, Issue: 7, Pages: 2340-2344, 2019, ISSN: 1816-949X, DOI: 10.3923/jeasci.2019.2340.2344,

http://medwelljournals.com/abstract/?doi=jeasci.2019.2340.2344

[18] Muhith, A dkk (2019). Health care Quality and Justice Quality: Its Effects on Patient Satisfaction in the National Health Insurance Era, Jurnal KnE Social Sciences, Halaman 549 567, 2019/3/24. url: https://knepublishing.com/index.php/Kne-Social/article/view/4034/8306

[19] Muhith, A dkk (2019). Modelling of SO 2 and CO pollution due to industry PLTD emission Tello in 2 Makassar Indonesia . Journal of Engineering and Applied Sciences Year: 2019 Volume: 14 | Issue: 2 | Page No. 634-640. ISSN: 1816-949X. DOI: 10.3923/jeasci.2019.634.640 url: https://www.medwelljournals.com/abstract/?doi=jeasci.2019.634.640

[20] Muhith, A dkk (2019). Spatial Pattern and Social Evironmental Risk Factors of Leprosy Occurrence in Barru, Indonesia. Publiser Journal The Lancet, 10 Pages Posted:10 April 2019. THELANCETID-D-19-00461. https://papers.ssrn.com/sol3/papers.cfm?abstract id=3367052

[21] Muhith, A dkk (2019). Structural Equation Modeling: Community Empowerment on Health Status and Pregnant Women Nutritional. Journal of Engineering and Applied Sciences Volume 14 Issue: (7): Page No.2385-2392, (2019). ISSN: 1816-949X. DOI: 10.3923/jeasci.2019.2385.2392

http://medwelljournals.com/abstract/?doi=jeasci.2019.2385.2392

[22] Muhith, A. (2018). Aplikasi Comunication Terapeutic Nursing \& Health Yogyakarta: publihser CV.Andi.

https://books.google.co.id/books?hl=en\&lr=\&id=fL9jDwAAQBAJ\&oi=fnd\&pg=PR5\&dq=info: yYZ5d6KCWPcJ:scholar.google.com\&ots=phcESQdDP0\&sig=jC-

09hHXfvQxHbGAbuVF8b0m-ZQ\&redir esc $=\mathrm{y} \# \mathrm{v}=$ onepage\&q\&f=false

[23] Muhith A, dkk (2018). Relationship of Sleep Quality with Student Learning Motivation in Nursing Academy 17 of Karanganyar, Indian Journal of Public Health Research \& Development, Volume. 9 Number 12. First page Pages: 1410-1413. Published: Dec 2018 Print ISSN: 09760245 Online ISSN: 0976-5506 DOI: 10.5958/0976-5506.2018.02051.X, url: http://www.indianjournals.com/ijor.aspx?target=ijor:ijphrd\&volume $=9$ \&issue $=12$ \&article $=255$

[24] Muhith A., dkk (2018). The spatial patten and risk factors of leprosy occurence in barru indonesia. Medicine: Public health, Evironmental and Occupational Health. Indian Journal of Public health Research \& Development. Volume 9, First Number 8. page 1489-1494. (08 Agustus 2018), ISSN 0978-0245 (print), ISSN 0976-5506 (Electronic). DOI Number: 10.5958/0976-5506.2018,00943.9.

http://www.indianjournals.com/ijor.aspx?target $=$ ijor:ijphrd\&volume $=9 \&$ issue $=8 \&$ article $=251$

[25] Muhith, A dkk (2018). Analysis of Educational Factors, Interest and Motivation Towards the Behavior of Early Detection of Cancer Cerviks in Women of Fertile Age in the Upt Health Center Kembangbahu Indian Journal of Public Health Research \& Development Volume. 9 Number 12. First page 1371-1375. Published: Dec 2018 Print ISSN: 0976-0245 Online ISSN: $\begin{array}{llll}0976-5506 & \text { DOI: } & 10.5958 / 0976-5506.2018 .02044 .2 & \text { url: }\end{array}$ http://www.indianjournals.com/ijor.aspx?target=ijor:ijphrd \&volume $=9 \&$ issue $=12 \&$ article $=248$ 
[26] Muhith, A., dkk (2018). Relationships between lead contaminated seafood consumption and blood pressure among fisherman communities at the Makassar Coastal Areas, Indonesia. Source: INDIAN JOURNAL OF PHYSIOTHERAPY AND OCCUPATIONAL THERAPY - AN INTERNATIONAL JOURNAL Volume: 12 Issue: 4 Pages: 186-191. Published: Oct 2018 Print ISSN: 0973-5666 Online ISSN: 0973-5674 DOI: 10.5958/0973-5674.2018.00104.1 url:

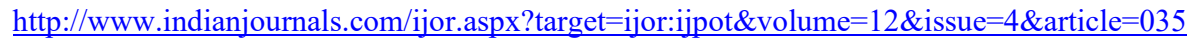

[27] Muhith, A., dkk (2018). Working climate with fatigue levels of timber industry workers in probolinggo. Source: INDIAN JOURNAL OF PHYSIOTHERAPY AND OCCUPATIONAL THERAPY - AN INTERNATIONAL JOURNAL Volume: 12 Issue: 4 Pages: 225-229. Published: Oct 2018 Print ISSN: 0973-5666 Online ISSN: 0973-5674 DOI: 10.5958/09735674.2018.00111.9.

http://www.indianjournals.com/ijor.aspx?target $=$ ijor:ijpot\&volume $=12 \&$ issue $=4 \&$ article $=042$

[28] Muhith, A., dkk (2018). The Effectiveness of Health Education on Improving Santris' Knowledge about the Dangers of Scabies at Al Mubtadi'ien Bahrul Ulum Tambak Beras Jombang. Source: INDIAN JOURNAL OF PUBLIC HEALTH RESEARCH \& DEVELOPMENT Volume: 9 Issue: 12 Pages: 1421-1425, Published: Dec 2018 Print ISSN: 0976-0245 Online ISSN: 0976-5506 DOI: 10.5958/0976-5506.2018.02053.3 url http://www.indianjournals.com/ijor.aspx?target=ijor:ijphrd\&volume $=9 \&$ issue $=12 \&$ article $=257$ 